and X-ray reproductions. An exception to this stricture is the volume by Fitzgerald Finch which covers modern imaging techniques well in text and illustration. This is an area that is not always well covered in nephrological text books and should be a useful and worth-while purchase.

However, many people will consider these volumes rather expensive when in toto they add up to an evening's read, albeit a good one.

\section{Willis's Oxford Lectures}

By Kenneth Dewhurst. Pp. $x+182$ illustrated. Sandford Publications, Sandford-on-Thames, Oxford, 1981. £9.00.

Thomas Willis (1621-1675) was an Oxford physician with an original research mind, and an applied pharmacologist and therapeutics specialist in an age when chemotherapy was empirical. He used Peruvian bark or quinine in the treatment of quartan fevers and his 'spirits of piss' was made by distilling dung mixed with urine from a 'sound man that drinks wine'. His practice flourished because of or despite such formidable cocktails.

This book will not help postgraduates through their higher examinations or diplomas but it will recapture the life and times of an Oxford restoration medical genius and it will introduce them to the secret potions of iatrochemistry. Perhaps this is what we need for some of today's untreatable psychosomatic ills of man. This book is a cultural pearl and we should salute and congratulate the author, the Wellcome Trustees and the publishers for an artistic heirloom.
Wound Healing. Principles and Practice.

By T. T. IRvin. Pp. 221, illustrated. Chapman and Hộl, London, 1981. £15.00.

It goes without saying that an understanding of the pract局al aspects of wound healing is essential for all surgeons. Moreover, the technical steps in the closure of an abdomifal laparotomy scar, or the fashioning of an anastomosis, The repair of an artery or the suture of a divided nerve, $\mathbf{P}$ re absolutely fundamental steps in safe and effective surgetoy. The author of this short monograph is himself a well known expert who has published widely on several of the cliniffal and experimental aspects of the subject.

There is an introductory chapter on the healing wotrid which gives a full account of the cellular and biochemical changes in the healing soft tissue wound. The healing of bogie, peripheral nerve, tendon and blood vessels are described isa later section. There is then a detailed chapter on factors, beth local and general, affecting wound healing and here therejis an up-to-date account of modern work on uraemia, zigic deficiency, etc. An important chapter deals with woưnld infection, its causes, prophylaxis and treatment. Woufpd healing in abdominal surgery calls for a separate chapter which deals with the healing of anastomoses and of the abdominal wall as well as dealing with entero-cutane fistulae. Wound healing in plastic surgery and the management of traumatic wounds also deserve separate chapters?

The text is clearly written and the illustrations, both in tte form of line diagrams and photographs, are first class.

This is certainly a book which surgical trainees work for their higher examinations will find of great value. 